\title{
Eötvös, Baron József. 2015. Poverty in Ireland 183 7-A Hungarian's View - Szegénység Irlandban. Trans. Paul Sohar and László Bakos. Dublin: Phaeton Publishing Ltd.
}

\author{
Reviewed by Tadhg Ó hAnnracháin*, University College, Dublin
}

This very interesting and welcome text by Hungarian writer and politician Baron József Eötvös (1813-1871), which presents the Hungarian original and the English translation on facing pages, is in a sense the hidden (and earlier) analogue of Arthur Griffith's much more famous 1904 Resurrection of Hungary - A Parallel for Ireland (accessible at:

archive.org/stream/resurrectionofhu00grifiala/resurrectionofhu00grifiala_djvu.txt). Whereas Griffith drew inspiration for Ireland from Hungary's achievement of equality of status within the Habsburg Empire, Baron Eötvös's belief in the need for major political reform in his native country, after centuries of domination by németek or Germans, was sharpened by his experience of the appalling conditions that he encountered on his 1830s visit to Ireland. Parallels can also be drawn between Eötvös and those Irish Protestant nationalists who for most of the nineteenth century represented a powerful leadership current in the movements to alter the nature of the constitutional relationship between Britain and Ireland. Like those (mainly) men, Eötvös came from privileged stock that had thrived on loyalty to Imperial power but who also were moved to imagine wider loyalties and possibilities in the context of the ferment of popular and romantic nationalism in nineteenth-century Europe.

Eötvös can in addition be set in a wider tradition of European liberalism, of individuals such as those German travellers recently explored by Eoin Bourke in his "Poor Green Erin": German Travel Writers' Narratives on Ireland from before the 1798 Rising to after the Great Famine (Bern: Peter Lang Internationaler Verlag der Wissenschaften, 2012), who genuinely admired England as a politically emancipated and enlightened society, but who were so deeply shocked by the conditions in Ireland that they were forced to question their respect for the British political system. As Eötvös notes: “...we saw Ireland and pity alone replaced the respect we had [for England]" ['láttuk Irlandot, s szívünk csak szánakozást érez régi tisztelete helyett'] (4-5). Finally, this text also usefully reminds us of the extraordinary reach enjoyed by the oratory and political philosophy of Irish political leader Daniel O'Connell, as expressed in his speeches in the House of Commons and in the time's newspapers, in particular in the wake of the achievement of Catholic Emancipation.

While Eötvös was not blind to the existence of poverty in England, which he related to the nature of its industrialization, he saw the appalling conditions of Ireland as qualitatively

*tadhg.ohannrachain@ucd.ie

$($ (c) $)$ EY

ULIS D-Sente
New articles in this journal are licensed under a Creative Commons Attribution 4.0 International License.

This journal is published by the University Library System of the University of Pittsburgh as part of its D-Scribe Digital Publishing Program and is cosponsored by the University of Pittsburgh Press 
Ó hAnnracháin, Tadhg. "Eötvös, Baron József. 2015. Poverty in Ireland 183 7-A Hungarian's View - Szegénység Irlandban. Trans. Paul Sohar and László Bakos. Dublin: Phaeton Publishing Ltd.” Hungarian Cultural Studies. eJournal of the American Hungarian Educators Association, Volume 10 (2017 DOI: 10.5195/ahea.2017.297

different. And it was this conundrum that he sought to confront. Differences between Vevey and Geneva could at least be explained by different political systems, "but England and Ireland exist under the same government" ['de Anglia s Irland egy kormány alatt él'] (12-13). Eötvös's account combined a strong concern with providing sources and a keen eye for detail together with an attempt to discern broader patterns underpinning the appalling situation in Ireland. A sense of humanity and an awareness of the degrading power of poverty therefore pervades his text: "As a cotter put in in response to a question, it is hard for someone to be diligent who has no hope ever of escaping debt and cannot see anything he can do to change this" ['Nehéz, így szól egy kérdezett zsellér, oly embernek, ki fülig adósságban van, iparkodónak lenni, maga sem tudja, hová nézzen'] (40-41). But he was also alert to the inability of any system of justice to function in the absence of a sense of popular legitimacy. In considering "mezei vétkek" ['agrarian crimes'] (42-43), he believed that only in Ireland could such acts of violence be domesticized under so innocent-sounding a sobriquet, and he noted acutely that the public approval for serious crimes against both person and property utterly undermined the administration of justice, which depended on a compact wherein "public opinion gives authority to court rulings" ['a közvélemény adja súlyát a törvényes itéletnek'] (46).

In trying to establish the causes of the ruinous state of Ireland's poverty, Eötvös first rejects a number of opinions that he ascribes to English journalists. For example, he strongly disbelieves that the Catholicism of the Irish is an intrinsic aspect of the problem. For Eötvös no religion, and certainly not Catholicism, should impede human endeavour, as the Catholic regions of Lombardy, France, Belgium and Germany indicated. Nor are, in his opinion, the economically relatively minor tithes to the Established Church a significant problem. The time's statistics also indicated that the common argument concerning over-population was invalid. Galway, for example, had an acre more per person than the prosperous farming counties of Kent and Wiltshire (53), although Eötvös's calculation in this respect does not take into account the differences in soil fertility. While the absenteeism of landlords provided an easy stick with which to beat this class, neither could this be taken as a root cause for the island's poverty.

Eötvös also denies the fifth commonly-adduced reason, namely the absence of Poor Laws, whose utility he doubted in primarily agricultural countries. Rather, he believed that no human being was diligent by nature and he saw the provision of governmental "workfare" as a chimera rather than a solution to the endemic problems. Behind these journalistic opinions, Eötvös was conscious that for many English observers the root cause of the problem was the idleness and despicable nature of the Irish. For him, this was hardly surprising: "No tyrant admits his power is unjust, and every tyrant tries to justify his inhumanity by asserting that those he oppresses are degenerate and unfit for freedom" ['Nincs zsarnok, ki nem érezné hatalmának igaztalanságát, s az emberi jogoknak nem hódolna legalább azáltal, hogy elnyomottját elfajultnak s a szabadságra érdemetlennek hirdeti'] (65-66). To Eötvös such sentiments were blasphemous: God had created people equal and all could rise or fall depending on circumstances. And Eötvös locates the true index of a people's morality in three characteristics: "family life, sense of nationhood, and depth of religious feeling" ['családi élete, nemzetiségének feltartása s a vallásosság'] (68-9), all of which the Irish fulfilled.

If commonplace opinions were inadequate, Eötvös sought a historically-based resolution to the conundrum of Irish poverty; therefore, the second part of the text provides a sweeping overview of Irish history to that end. While considering that even in the medieval period the Irish had resisted assimilation and that the English discriminated against them, for Eötvös the critical 
Ó hAnnracháin, Tadhg. "Eötvös, Baron József. 2015. Poverty in Ireland 183 7-A Hungarian's View - Szegénység Irlandban. Trans. Paul Sohar and László Bakos. Dublin: Phaeton Publishing Ltd.” Hungarian Cultural Studies. eJournal of the American Hungarian Educators Association, Volume 10 (2017 DOI: 10.5195/ahea.2017.297

moment occurred with the Reformation, which he saw as starting a new era in Irish history (79). Difference in religion led to programmatic conflict and conquest, in which the native elites were replaced from England and consequently the interests of Ireland "were always secondary to England, with the result that the good of the nation was always sacrificed for the benefit of the privileged group planted there by England, and that group was always eager to serve the English Tyranny in return for its support" ['mindig Anglia érdekeinek alárendeltettek, s hogy így az ország java maga privilegiált osztály által önkényt feláldoztatott, cask hogy Anglia által zsarnoki hatalmában, melyet a nép felett gyakorlott, pártoltassék'] (90-91).

This situation reached its apogee in the Penal Laws, which Eötvös saw as central to the nation's degradation and about which he quoted Edmund Burke that they represented a worse corpus than had ever been enacted by a Catholic state against heresy. He rehearses these laws at length in the text and, although he acknowledges that in many respects they were not fully enforced, he wholeheartedly endorses the contemporary observation of Gustave de Beaumont: "Far from admitting that the suspension of bad laws allows some happiness to the people, I say, on the contrary, that bad laws are never so pernicious as when they are dormant... it is one of the most dangerous acts of tyranny, to choose among its instruments those which plunder without wounding" ['Nemhogy azt hinném, hogy rossz törvényeknek álma nemzeteknek némi boldogságot enged; én ellenben azt mondom, hogy rossz törvények soha nem károsabbak, mint mikor alszanak.... ez egyike a zsarnokság legveszedelmesebb mesterségeinek, hogy eszközei között azokat választja, melyek megfosztanak, de anélkül, hogy sértenének'] (108-109). Overall, the result of institutionalized discrimination was a vicious partiality on the part of the law.

The third part of the text attempts to discern whether a brighter future for Ireland was possible. Eötvös does not see flatly economic solutions as the answer. As previously noted, he doubts the efficacy of Poor Laws, he does not believe in industrialization as a means to advance the common good, however enormous the personal fortunes that might be made, and he rejects the idea of forced emigration as both economically impractical and outrageously cruel. Fundamentally, he argues for a political solution, namely the institution of genuinely just government in Ireland. Once this occurred it would require individuals such as O'Connell, whom he praises for their magnificent denunciation of injustice, to quieten their voices and still the clamour of rebellion. Underpinning his hope in the possibility of a much brighter future are two principal convictions: the first is a firm religious belief in Divine providence and benignity: "God does not want his peoples to be slaves on the earth" ['Isten nem akará, hogy népei szolgák legyenek e földön'] (120-122), and thus the oppressed were created never to forgo their innate rights nor tyrants to remain fixed in their sinful paths. The second is the contemporary movement of social progress and advancing morality that he discerns and the hope he derives from Benthamite ideas concerning profit and morality, merit and reward.

Baron József Eötvös's Poverty in Ireland 1937 is a wonderful text that offers a reflective early-mid nineteenth-century observation on Ireland of less than a decade before the social and demographic cataclysm of the Great Famine. It offers a fascinating insight into the worldview of the social reforming elite of Hungary, too, and onto Ireland's status during the period as a burning issue for European liberals in their consideration of British political structures. As can be seen from the quotations above, at times the translation of the Hungarian original, offered us by the able hands of Paul Sohar and László Bakos, is somewhat free, yet it admirably renders the sense of the source text. 